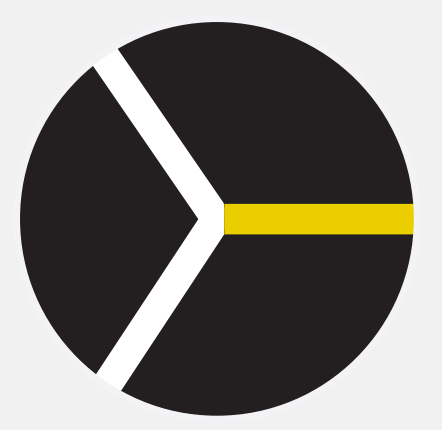

TECHNOLOGY GOVERNANCE

\title{
The periphery paradox in innovation policy: Latin America and Eastern Europe Compared
}

Some reflections on why it is not enough to say that innovation matters for development

\section{Draft}

Rainer Kattel and Annalisa Primi*

March 2010

\footnotetext{
- Tallin University of Technology, Estonia. Research for this article was partially funded by Estonian Ministry of Education and Research (targeted financing grant no SF0140094s08) and Estonian Science Foundation (grants no 7577, 6703 and 7441).

* OECD, Science and Technology Policy Division. The opinions expressed in this paper are those of the author and do not necessarily reflect those of the Organization. Corresponding author: Annalisa.primi@oecd.org.
} 


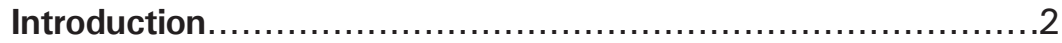

Production structure and incentives for innovation................. 4

The evolution of innovation policy.................................. 10

Latin America................................................... 11

Central and Eastern Europe....................................... 20

Policy models in a comparative perspective........................29

The 'pro-innovation' momentum: a way out from the

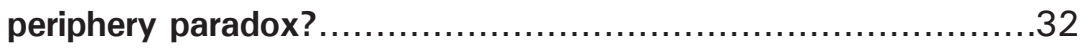

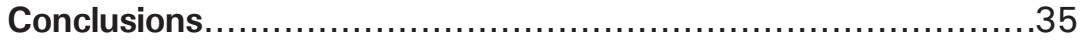

\section{Introduction}

The interest in innovation as a growth, competitiveness and well-being driver is nowadays a shared vision among countries at different levels of development. Most countries in the world have a national agenda (paper, policy) for innovation, with fairly similar priorities and objectives. This, at least, is true at the rhetorical level. Or to use the words of Gerad De Graaf, head of unit in charge of the Lisbon Strategy at the European Commission, "Everybody agrees that there should be more innovation. I have never met anybody in my life who says that 'I am against innovation'. Is anybody against panda bears? Or against Santa Claus?". This does not mean that countries all share the same view regarding what is innovation, why public policy should support it and how to do it. But this means that we are in a 'pro-innovation' era, even in non-frontier regions where in the recent past innovation and technological development were expected to naturally appear through trade and foreign investments. (ECLAC, 2008a, 2008b; Radosevic, 2009; OECD, 2009; UNIDO, 2009). 
This generalized interest in innovation in part derives from the current context shaped by newly established (ICT) and radically new (biotech and nanotech) technological paradigms which are transforming the way in which agents (individuals, firms and countries) produce, trade and invest, thus creating a situation in which the possibilities and spaces for innovation are multiple and different from the previous age (think for example about wide variety of successful business models, or the new ways of doing health-related research). In the global knowledge economy innovating has become imperative.

Latin America and Central and Eastern Europe are fairly different regions in terms of size, political dynamics, and prevailing economic specialization and trade patterns. However, both regions underwent similar reforms patterns since the decade of the 1990s which influenced the evolution of science, technology and innovation policy in a similar way. The Washington Consensus recipe marginalized science and technology (S\&T) policies and instead aimed at targeting inflation and at the reestablishment of macroeconomic stability through openness, privatization and deregulation ${ }^{1}$. In the 2000 s both regions faced a slow return of policies supporting innovation and competitiveness. However, besides the different reforms and the design of S\&T plans and policies, both regions are still marginal actors in the S\&T game. The reasons behind the persistence in aggregate scientific, technological and production backwardness are manifold. Among those reasons, the dynamics of the evolution of S\&T policies and the 'stop and go' approach induced by each wave of reforms which transformed those policies into a moving target is a key issue, usually not addressed by the innovation policy literature. Cumulativeness and path dependency do not affect only innovation dynamics; they also influence the evolution of policies.

In this paper we are interested in analyzing the dynamics of the innovation policy in non-frontier countries, and their relationship with structural change and development.

In the current context of redefinition of global powers, with new actors gaining ground in the knowledge game, like China, India, Russia and Brazil, frontier countries are reflecting on how they can support innovation and which type of innovation strategy they should pursue in the next decades to sustain their competitiveness and avoid losing ground with respect to emerging economies. Also, we can witness increasing efforts at generating better innovation policies to respond to emerging challenges such as environment and sustainability, pushing the innovation policy discourse back

\footnotetext{
1 For the discussion of the Washington Consensus see Williamson, 2002; Kregel, 2008; Rodrik,
} 2006. 
into a systemic approach of policy mix to support the varieties of capabilities needed for innovating in the new economic era. In addition, the financial crises has, on the one hand, steepened the catching up climb for many developing countries as they lack the resources for fiscal stimulus programs to counter-balance the loss of export demand; while at the same time advanced economies increasingly recognize scientific capacities and entrepreneurial innovation capabilities as key assets for a successful way out of the crisis.

The pressure on developing economies to create capabilities for innovation is rising. Catching up and peripheral countries face more challenging task in creating and implementing effective innovation policies. For them, beyond the rhetoric that innovation matters for development, it is crucial to identify which types of innovations to support and how to do it, given the constraints posed by budgetary reasons and by trade incentives that tend to push towards specializing into low value added activities (ECLAC, 2008a). Analyzing the shortcomings of the past processes of reforms in S\&T and innovation policies might help to avoid incurring the same errors, and it could help in re-linking innovation policies to production development and to bring back into the policy debate the issue of the sectoral differences in science, technology and production which has been the missing issue in the innovation policy discourse since the structural reforms of the nineties ${ }^{2}$.

\section{Production structure and incentives for innovation}

When it comes to innovation, Latin America (LA) and Central and Eastern Europe (CEE) evoke two different stories. CEE is largely seen as a success story, especially in relation with the ICT boom. For instance, at the end of 2005, Business Week ran a cover story titled "Central Europe - Rise of a Powerhouse". ${ }^{3}$ LA, on the contrary, is generally seen as a region still struggling with catching up and which is at the margins of global knowledge economies (Cimoli et al., 2005; ECLAC, 2008a; 2008b).

However, besides the divergent perceptions, the two regions display similarities in terms of persistent gaps with frontier economies in terms of production structure specialization and aggregate innovation performance. In addition, both regions, besides the aggregate low performance, show high intra-regional heterogeneity and they both have a country which for size, political strategy and accumulated capacity plays on a different ground: Brazil and Russia, respectively.

\footnotetext{
2 Radosevic, 2009 offers a very good summary discussion on the topic.

3 Below we use CEE for the EU member states in the region, namely Bulgaria, the Czech Republic, Hungary, Estonia, Latvia, Lithuania, Poland, Romania, Slovakia, and Slovenia
} 
The experiences of Latin America and Central and Eastern Europe are particularly interesting, because the two regions have followed relatively similar development path since the decade of the nineties, i.e. growing integration into global trade and rising FDI, and, in the last decade, rising interest in innovation as a driver for economic growth. In addition, although coming from different experiences in the pre-Washington Consensus era (i.e., import substitution and the Soviet system), both regions were, at the time of liberalization, in the process of construction and consolidation of endogenous capabilities for science and technology.

Currently, despite the public policy efforts, which anyway remain low in comparison to frontier countries, both regions display a persistent gap in innovation capabilities and efforts. Investment in R\&D is not on a rising trend; investment in human resources for S\&T is yet marginal, while outcome indicators are not encouraging as well, take the low number of scientific publications and patents, for example.

A comparative look at R\&D investment trend shows the asymmetry between Latin America, Central and Easter Europe and the rest of the world (see Figure 1). Early industrializers such as the USA and the 'old' European countries show almost stable expenditure in R\&D as a \% of GDP since 1990. Relatively recent catching up countries, like Finland and South Korea, have markedly increased their $R \& D$ efforts. This growth has been the result of a deep structural change that transformed those economies into high tech producers and exporters thanks to the implementation of policies tailored to strengthen domestic technological capabilities. ${ }^{4}$ On the contrary, Central and Easter European countries decreased the intensity of R\&D investments, due to the change in the prevailing policy model. Latin American countries, in turn, show persistence in the marginal R\&D effort, which is consistent with the marginal changes that occurred in its production structure along the last two decades.

\footnotetext{
4 Hobday, 2009 offers an excellent discussion of evolution of East Asian industrial and innovation policies in response to changing technological paradigms during the last five decades. On Finland, see Ylä-Anttila and Lemola, 2006.
} 
Figure 1. R\&D INVESTMENT AS \% OF GDP, SELECTED COUNTRIES AND REGIONS ${ }^{5}$

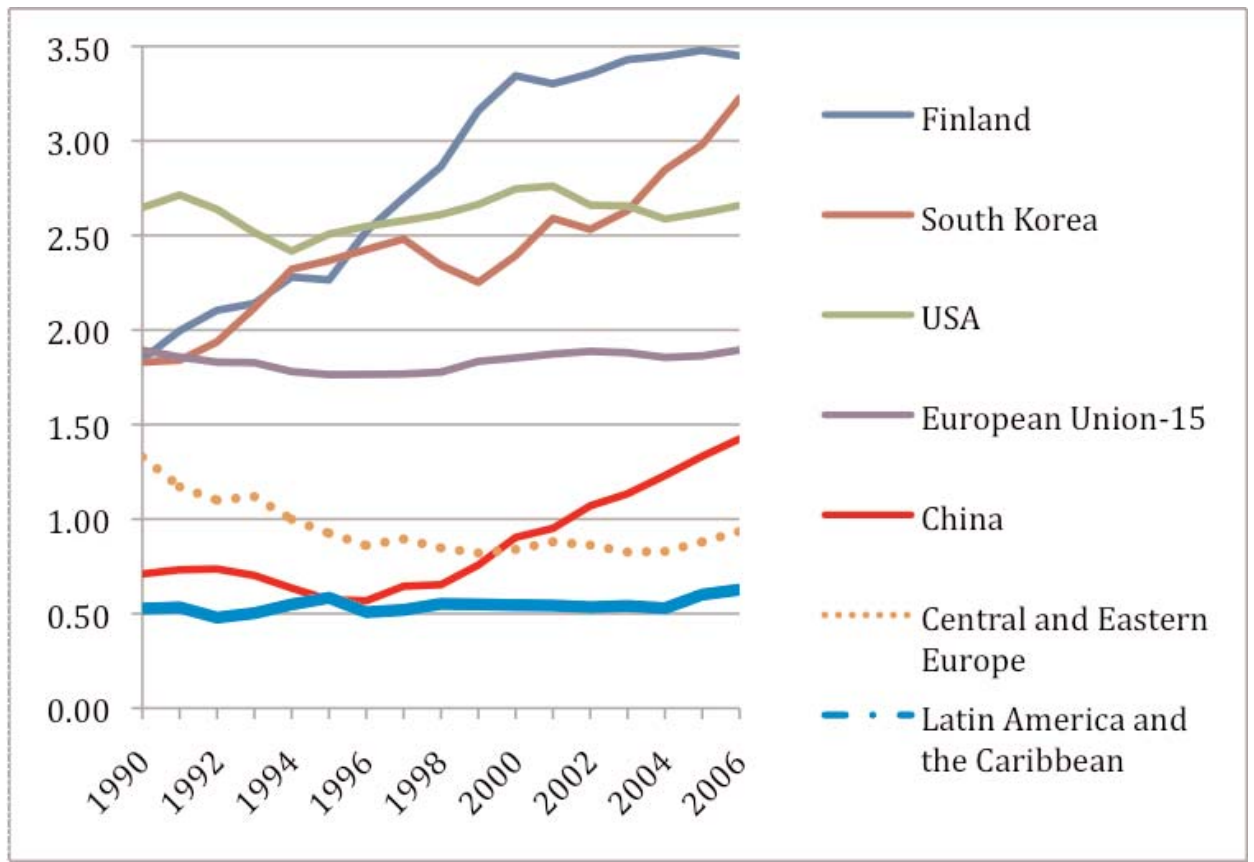

Source: OECD-MSTI Database, RICYT.

The asymmetry with frontier countries persists when we look at the expenditure on $R \& D$ by sector of performance. In frontier economies firms carry out the majority of R\&D activities, followed by higher education institutes and the government. In Central and Eastern Europe similarly the private sector delivers the majority of R\&D activities; however, the involvement of the private sector in R\&D is lower than in more industrialized countries. ${ }^{6}$ The pattern in Latin America differs; the majority of $R \& D$ is executed by the government or by the higher education sector (Table 1 ).

\footnotetext{
5 Central and Easter European data consists of the average of Czech Republic, Hungary, Poland, Slovak Republic, Romania and Slovenia.

6 CEE picture changes quite significantly when one adds the Baltic countries and Bulgaria and Romania; the private sector share decreases.
} 
Table 1. R\&D EXPENDITURE BY SECTOR OF PERFFORMANCE, 2006 (\%)

\begin{tabular}{|c|c|c|c|c|}
\hline & Government & Enterprises & $\begin{array}{l}\text { Higher } \\
\text { Education }\end{array}$ & $\begin{array}{l}\text { Private non- } \\
\text { profit }\end{array}$ \\
\hline Latin America and the Caribbean & 20 & 40.9 & 37.1 & 2 \\
\hline Argentina & 40.7 & 30.4 & 26.5 & 2.5 \\
\hline Bolivia (2002) & 21.0 & 25.0 & 41.0 & 13.0 \\
\hline Brazil (2004) & 21.3 & 40.2 & 38.4 & 0.1 \\
\hline Chile (2004) & 23.0 & 26.6 & 41.8 & 8.6 \\
\hline Colombia & 8.3 & 22.2 & 52.8 & 16.7 \\
\hline Costa Rica (2004) & 17.0 & 28.0 & 34.0 & 21.0 \\
\hline Ecuador & 75.5 & 19.0 & 4.2 & 1.3 \\
\hline Mexico) (2005) & 23.2 & 46.9 & 28.7 & 1.1 \\
\hline Panama (2005) & 37.1 & .. & 8.6 & 54.2 \\
\hline Paraguay (2005) & 14.6 & 38.5 & 35.4 & 11.5 \\
\hline Peru (2004) & 25.6 & 29.2 & 38.1 & 7.1 \\
\hline Trinidad and Tobago (2004) & 54.3 & 23.7 & 21.9 & .. \\
\hline Uruguay (2002) & 19.4 & 49.0 & 31.6 & 0.0 \\
\hline \multicolumn{5}{|l|}{ Central and Easter Europe } \\
\hline Check Republic & 17.5 & 66.2 & 15.9 & 0.4 \\
\hline Hungary & 25.4 & 48.3 & 24.4 &.. \\
\hline Poland & 37.0 & 31.5 & 31.0 & 0.4 \\
\hline Slovak Republic & 32.8 & 43.1 & 24.1 & 0.1 \\
\hline Slovenia & 24.1 & 60.2 & 15.1 & 0.2 \\
\hline Russian Federation & 27.0 & 66.7 & 6.1 & 0.3 \\
\hline United States & 11.3 & 71.0 & 13.5 & 4.2 \\
\hline Total OECD & 11.4 & 69.1 & 17.2 & 2.6 \\
\hline EU-15 & 12.7 & 63.9 & 22.3 & 1.2 \\
\hline Finland & 9.3 & 71.3 & 18.7 & 0.6 \\
\hline Japan & 8.3 & 77.2 & 12.7 & 1.9 \\
\hline Korea & 11.6 & 77.3 & 10.0 & 1.2 \\
\hline China & 19.7 & 71.1 & 9.2 &.. \\
\hline Singapore & 10.3 & 65.7 & 23.9 & 3.7 \\
\hline Israel & 5.3 & 77.2 & 13.7 & 0.3 \\
\hline
\end{tabular}

Source: RICYT, OECD-MSTI Database and UNESCO..

As for trends in higher education, more similarity appears with respect to frontier economies. Both LA and CEE substantially increased the stock of skilled human resources form the 1970s onwards, however the gap with advanced countries persists, as Figure 2 shows. 


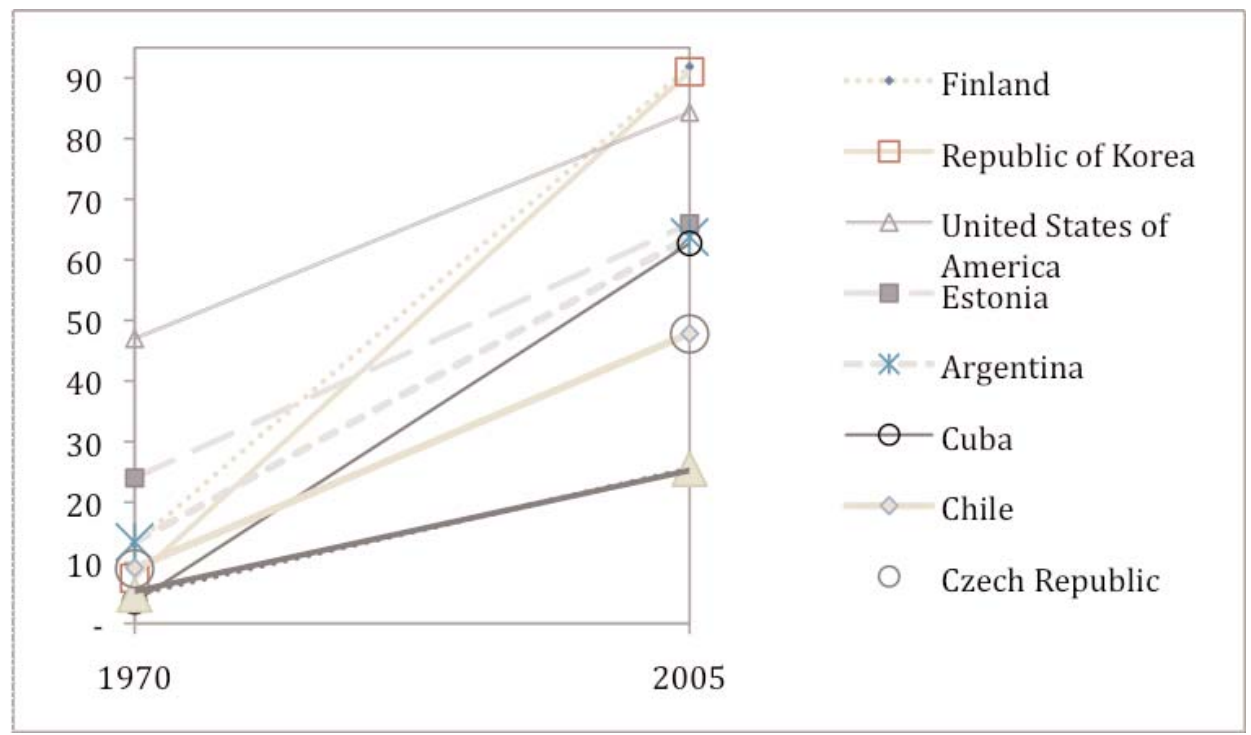

Source: UNESCO, 2009 Global Education Digest

Within the region there are differences which international cross-country comparisons hide. In Latin America, the more proactive countries in terms of R\&D spending are Brazil, Mexico, Argentina, Chile and Cuba, which as a whole account for almost $80 \%$ of regional spending. R\&D expenditure in Latin America is mostly carried out by the state, in contrast with more advanced economies; however patterns differ. In Argentina, Brazil, Mexico, Paraguay and Uruguay enterprises carry out more than $30 \%$ of total $R \& D$ spending, while in Ecuador and Colombia the participation of the private sector in R\&D execution is extremely low. The three countries with the highest ratio of researchers per million habitants in the region are Cuba, Argentina and Chile, while the ranking for absolute numbers of researchers is: Brazil, Mexico and Argentina. As for the mobility of graduate and post-graduate students, Argentina and Chile are the preferred destination within the countries of the region; even though the United States, the UK and Spain are the top foreign destinations for Latin American students. (ECLAC, 2008b)

In CEE there is a clear divide between countries in the European Union and those outside. ${ }^{7}$ The former exhibit relatively homogenous rates of

\footnotetext{
7 Besides Russia, these are former Soviet republics Ukraine, Belorussia and Moldova; and former Yugoslavian republics not in the EU (Croatia, Serbia, Bosnia-Herzegovina, FYR Macedonia, Montenegro, Kosovo).
} 
change (e.g. in high tech exports or FDI inflows; see further Kattel, Reinert and Suurna, 2009). The latter, however, with the exception of Russia perhaps, have seen enormous declines in technological development. (World Bank, 2008).

In general, Latin America and Central and Eastern Europe show 'periphery' features: co-existence of islands of technological excellence with a generalized low-tech and low-skilled labor production structure and marginal positioning in global production chains (ECLAC, 2004; ECLAC, 2008a; Kattel, Reinert and Suurna, 2009). In both regions, Brazil and Russia, for the accumulated scientific and technological capabilities and for current political strategies sustaining production development might play the role of regional geese. Although, for the CEE EU members, Russia plays less and less important role in trade; in particular Central European countries such as Slovakia, Hungary and the Czech Republic have achieved high levels of integration with the EU: merchandising exports in worth of up to $60 \%$ of GDP goes in these countries to the EU (IMF DOTS database). These countries have become the main trading partners for Germany.

Latin American and Easter European countries spend comparatively less on $R \& D$ with respect to frontier economies and invest less in the generation of human capital for scientific and technological activities. Latin America shows higher intra-regional heterogeneity in terms of technological specialization of the production structure with respect to Eastern Europe, which also appears to be relatively more specialized in high tech activities. This is not surprising considering that higher levels of $R \& D$ investments are generally associated with higher weight of high tech industries in domestic production structure (see Figure 3).

Different industries produce and innovate in a different way. An increase in $R \& D$ expenditure with a production structure oriented towards low technology industries is hardly to happen. The specialization pattern determines the prevailing innovation effort. Hence, incentives to increase R\&D investments need to be coupled with policies supporting production and entrepreneurship in key R\&D intensive sectors. 
Figure 3. TECHNOLOGICAL SPECIALIZATION AND INNOVATION EFFORT

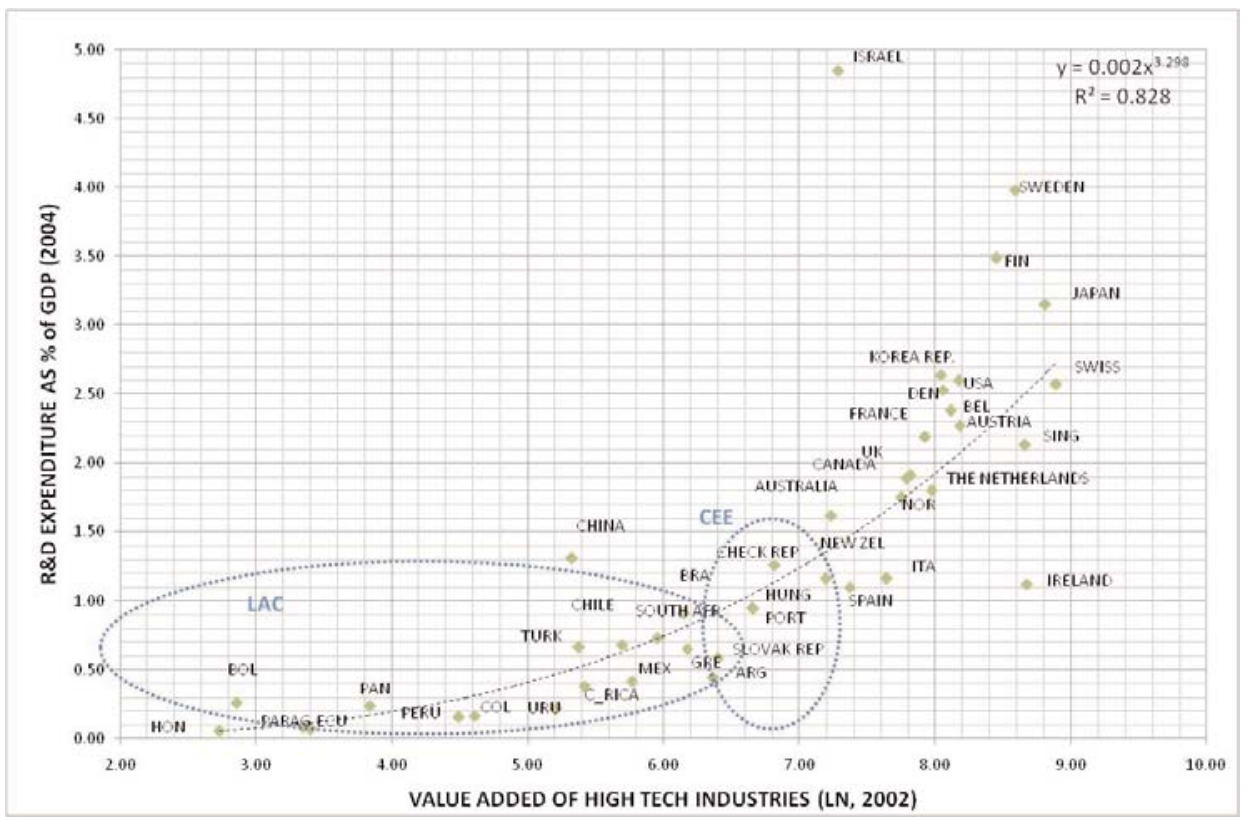

Source: ECLAC, CyT-DES (www.cepal.org/iyd

\section{The evolution of innovation policy}

The evolution of innovation policies in Latin America and in Central and Easter Europe followed similar patterns. In both regions the efforts related to the creation of domestic scientific and technological capabilities date back to around half a century ago, even though they were framed in two different policy models: the import substitution strategy and the Soviet planned economy. During those years, both regions experienced a period of deliberate state intervention focused to the construction of domestic scientific and technological capabilities.

As a consequence of the debt crisis, both regions experimented similar reform patterns. During the nineties the two regions followed the Washington Consensus market oriented approach to development. State intervention was almost banned and markets were supposed to take the lead for structural change and development. Increased integration into international trade and openness were understood to bring about the right incentives and competition to support modernization and innovation rationalizing investments and prompting efficiency. However, this was not the case, and liberalization clearly proved not to be enough for catching up. 
Microeconomic adjustments required more than openness and competition to transform production structures. The free market approach showed its limits in generating the rights incentives for innovation, and policies restarted to get legitimacy. The 2000s signed the transition to the postWashington Consensus strategy (Peres and Primi, 2009; Radosevic 2009). Innovation policies came back on the agenda, usually framed under the umbrella of the national innovation systems approach or as plans supporting competitiveness. The 2008 financial crisis might induce a new phase in innovation policy, as countries are urged to redefine investment plans. A brief description of innovation policy in LA and in CEE follows.

\section{Latin America ${ }^{8}$}

During the fifties and sixties, government actions, which nowadays would be labeled S\&T policies, aimed at creating the institutional infrastructure for S\&T and at fostering the generation of endogenous scientific and technological capabilities in national priority areas, in line with the industrialization strategy of local production capacities expansion. Government action targeted the creation of scientific and technical knowledge in priority areas for national development. The state owned firms and carried out $R \& D$ activities in strategic sectors like transport and telecommunication; while public research institutes supported research in agriculture, energy, mining, forestry, and the aeronautics sector (ECLAC, 2004; Cimoli, Ferraz, Primi, 2005).

Governments invested in the creation of the basic scientific and technological infrastructure to support the national industrialization effort in key scientific and technological areas. For instance, Argentina instituted the National Atomic Energy Commission (CNEA) in 1954 and in 1957 the Institute for Industrial Technology (INTI). The main function was the provision of technology services to state owned companies. ${ }^{9}$ Correspondingly Mexico opened the National Institute for Nuclear Research (ININ), the Electronics Research Institute (IIE), the Mexican Institute for Water Technology (IMTA) and the Mexican Petroleum Institute (IMP). Consistently with a selective industrial focus, Brazil created a series of sectoral institutions. In the early fifties was established the Aerospace Technology Centre (CTA), while almost twenty years later, in 1973, was set up the Agricultural Research Enterprise (EMBRAPA), (Burlamaqui et al., 2007). According to the predominant logic of state intervention as an engine of growth, many public enterprises established their own research centers like ELETROBRAS'

\footnotetext{
8 This sub-section draws on Cimoli, Ferraz and Primi (2005).

9 For additional information about Argentina, see Yoguel (2003); for Mexico Casalet (2003); for Brazil Pacheco (2003) and Burlamaqui et al. (2007).
} 
Electrical Energy Research Centre (CEPEL) and the Leopoldo Américo M. de Mello Research and Development Centre (CENPES) run by PETROBRAS (ECLAC, 2004; Pacheco, 2003).

This policy model contributed to the creation of S\&T infrastructure, creating the basis for future technological upgrading. At the same time, the model was weak in coordinating different sectoral agencies leading to overlapping initiatives and consequent waste of resources (Capdevielle, Casalet and Cimoli, 2000; ECLAC, 2004; Yoguel, 2003).

In the eighties, the debt crises and the 'lost decade' diverted the attention from the long-term industrialization effort. Short-term inflation targeting policies prevailed. Macroeconomic stability was the priority, and there was no much room left for policies to foster capability accumulation. In addition, the out-of-crisis recipe (proposed by international financial institutions, and well accepted by most of the governments of the region) transformed state intervention into the less desirable tool for technological development.

Open and global markets were supposed to guarantee efficient allocation of resources and ultimately technological upgrading in the region. Capital goods imports, technology licensing and the need to compete with foreign and more technologically advanced firms would have put the enough pressure on domestic firms for modernization and innovation. Actually, Latin American countries modernized their production apparatus, thanks to those channels. However, modernization remained circumscribed to leading and larger firms and it did not trickled down to the rest of the production structure, contributing to increase the structural heterogeneity within and between the countries of the region, (ECLAC, 2008a) Furthermore, Washington Consensus reforms partially deepened macroeconomic problems inherited from 1970:

"a rapid increase in external financing (much of which was not used for import substitution at all), such as the one that occurred in the 1970s, places a heavy burden on a country's balance of payments that can only be financed by increased foreign borrowing. This appears to have been the case in Latin America in the 1970 s as increased borrowing was used to meet increasing debt service in a sort of Ponzi scheme. ... The problems that were faced by import substitution industrialization were caused as much by the inappropriate and potentially incendiary mix of financing domestic import substitution industrialization through private external financial flows as in the inherent difficulties in building sufficiently large domestic markets to support competitive domestic industry and avoid rent-seeking behavior", (Kregel 2008). 
These changes favored the generation of an industrial structure that 'per se' expresses a scant demand for knowledge, thus implicitly limiting the potential positive stimuli effect towards technological catch up of liberalization and increased competition. In contrast, the Asian economies like Korea and Taiwan, followed by Malaysia, Thailand and Indonesia, were successful in creating expanding capabilities in technology intensive industries and production stages, combining selective import substitution policies with aggressive, but gradual, export oriented strategies. ${ }^{10}$

The rationalization of regional production processes resulted in a 'truncated' modernization because the leapfrog towards effective domestic technological upgrading is still to be done. Technological upgrading entails the development of endogenous capabilities through complex, dynamic and collective trial and error processes, which need to be backed up by targeted policies. In the new global knowledge economy, with increasingly powerful foreign actors and weak domestic scientific and technological infrastructure, market incentives push firms to increasingly rely on foreign sources of knowledge. At the same time, the few local results of innovation and technological upgrading tend to be transferred abroad, and not to be appropriated locally.

The rising prices of commodities in the last years, the improvement in the terms of trade for natural resources and the consequent appreciation of regional exchange rates have reduced the incentives for production diversification in favor of technological capabilities, undermining S\&T policy effectiveness and implementation. A self-reinforcing process of concentration in fewer activities took place, reducing the incentives to learn and invest in other sectors. (ECLAC, 2008a)

The science and technology policy model of the nineties emphasized the role of markets incentives and of demand side in priority setting. The support to technological upgrading and to private sector innovation focused on areas where market failures occurred; i.e. public policies priority was merely correcting information asymmetries between economic agents. This stance towards public policy meant placing knowledge and innovation on an equal footing with information accessibility. In effect, a conceptual linearity associated with the process of knowledge generation and technology diffusion persisted. Knowledge was supposed to follow bottom-up nonhierarchical pattern, in a setting where the engine for innovation generation was the supposed spontaneous demand of the private sector, acting as a major technology booster.

\footnotetext{
10 The literature on the 'Asian miracle' is vast; for some analysis sustaining the role of policies see Amsden, 1989; Jomo, 1997 and Wade, 1990. For a comparative analysis of the evolution of industrial development and technological capabilities between Latin American and Asian economies see Cimoli et al., 2006.
} 
The shift in policy models entailed institutional and organizational changes. New management styles were introduced and new institutional bodies were created. In Argentina, for instance, the restructuring of S\&T institutional infrastructure led to an increase in coordination among different bodies, partly overcoming what represented a structural limit of the previous period. In Mexico, in turn, the priority was the decentralization of S\&T institutional management, according to the different technological and specialization patterns of various Mexican regions.

Beyond countries' peculiarities, the reorganization of institutions generally brought about: i) increments in resources and in the relevance of those S\&T agencies dedicated to capture private sector demand for technology and knowledge, ii) an incipient interest towards greater articulation and coordination between private and public sector, resulting in cross-countries augmented interest in universities-enterprises connections and, iii) changes in competencies and objectives of agencies. S\&T priorities shifted from basic research to the provision and commercialization of technological services, mainly oriented to support production process management and quality control. Reward systems and management styles of S\&T institutions changed as well, moving towards practices that are more in line with market mechanisms and incentive schemes, privileging performance based models of evaluation and allocation of priorities. Accordingly, the role of international financial institutions as source of financing for S\&T augmented.

In the more recent years, policies started to gradually regain a certain degree of legitimization, usually under the label of policies for competitiveness or cluster development. Such policy evolution naturally entailed a national based focus of policies and instruments. The primary effort of building domestic capabilities and infrastructure, as well as the focus on competitiveness required a national consensus and a primary look at the country's needs and priorities.

The management of policies for science technology and innovation follows different institutional arrangements in the countries of the region. Argentina, Brazil, Cuba, Costa Rica and Venezuela have ministries for S\&T, while in the other countries the policy responsibility is placed in National Councils which, in general, respond to the Presidency, to the Ministry of Education or to the Ministry of Economy. Beyond asymmetries in institutional infrastructure, there are considerable differences among countries in terms of origins of funds, magnitude of administered budgets, objectives and priorities. Each country establishes its own science and technology policy, which is more or less formalized and contextualized according to the institutional development, the complexity of the production apparatus and 
articulation of the national innovation system ${ }^{11}$. The sets of instruments for S\&T policies are well known in the countries of the region. Usually the bottlenecks appear more at the level of implementation and management than at the level of policy design. In short three main issues might be highlighted: the instruments for supporting human capital formation and public private partnership, technology funds and the rising topic of IP management.

An area of general consensus is the support for human capital formation for S\&T. Brazil with its articulated system of grants and loans for financing university postgraduate studies forms around $7000 \mathrm{PhDs}$ per year and scores the highest in domestically formed $\mathrm{PhDs}$ in the region (accounting for more than $70 \%$ of total Latin American PhDs according to RICYT's estimates). Almost all countries have, at least at the level of policy design some measures to support human capital formation. In Argentina the 2004 Argentine National Plan for Technology and Production Innovation put in its forefront the strengthening of national scientific and technological base through supporting PhDs formation. In Chile the National Commission for Scientific and Technological Research (CONICYT) supports postgraduate training through a series of articulated pad-hoc programs oriented to assist PhDs formation within the country and through international networking. The Bolivian National Secretary for Science, Technology and Innovation, the Colombian National Program for Industrial and Technological Development 2000-2010 and the Uruguayan National Service for C\&T (SENACYT) and FUNDACYT support post graduate and doctoral human capital formation through credit and grants systems. In Costa Rica support to graduate and post-graduate studies is mainly coming from private universities, while in Mexico National Council for Science and Technology (CONACYT) allocates public funds for sustaining high level human capital formation and the Public Research Centres (CPI) directly intervene in human capital formation and subsidize it through grants which are financed by specific CPI's funds. According to a selective intervention strategy, in Peru the Genome Program finance postgraduate formation in genetics, while the Paraguayan 2002 National C\&T policy prioritize formation in the engineering and mining sectors, for example.

Resources to finance S\&T activities are channelled for the most part through technology funds. At the country level, deep differences emerge in terms of beneficiaries and targets (research centres, enterprises, and special treatment given in certain cases to SMEs), source of financing, i.e. national (private or public) and international, and in terms of access mech-

\footnotetext{
11 In November 2007, a group of countries of the region signed a protocol agreement expressing the political support for the generation of a regional dialogue for S\&T policies for increasing cooperation in S\&T policy formulation and implementation in the frame of the ECLAC activities for S\&T policies. The issue of regional cooperation in S\&T policy represents a key element in the management of S\&T policies in global knowledge economies (Primi, 2009).
} 
anisms (basically supply or demand-side mechanisms or mixed). Since the structural reforms, technology funds have been fostering the promotion of consultancies and technical assistance services aiming to reinforce R\&D in universities, research centres and enterprises. Two main categories of funds exist in the region: the one oriented to the demand and the other which emphasizes the coordination between demand and supply.

The demand subsidy scheme, which prevails in Argentina, Chile, Costa Rica and Mexico, channels public funds, or loans from international organizations, to S\&T activities subsidizing the demand by following a horizontal logic based on the evaluation of proposals and applications directly presented by potential recipients (enterprises or research centres). For instance, the Argentine Technological Fund (FONTAR) prioritize 5 areas in S\&T development: i) technological development of new products, services or production processes, ii) technological modernization, i.e. improvement of products and processes, training, iii) promotion of the technological services market, supporting research laboratories and business research centres activities, iv) training and technical assistance and v) technological advisory assistance programmes especially to strengthen small and medium-sized enterprises' technological performance. The fund, which allocate resources on the basis of a demand-pull mechanism, is made up of national financial resources originating from national budget, fiscal credit law, credit lines of public banks and of resources originating from international loans (IADB loans according to the Argentine Modernization Plan).

The FONTAR assigns financial resources to demanding beneficiaries principally in the form of non-repayable contributions, loans, subsidies and fiscal credit according to specific objectives and prospective beneficiaries. This kind of system, where access to incentives for innovation depends upon a direct initiative of potential targets, may lead to increasing heterogeneity in technological behaviours because it could ingenerate adverse selection mechanisms among recipients. In the demand subsidy scheme, incentives to recur to financial assistance for innovation are biased. More pro-active agents, which perhaps have a comparative advantage in technological upgrading, and that could probably master technological innovation without recurring to public funds will be more prone to submit projects for evaluation; while more technological backward actors will face higher barriers to participate in this scheme. A further weakness of the demand subsidy model is that a proper information dissemination policy is needed in order to allow beneficiaries to be aware of the possibility offered by the financing schemes. Most of the sub-utilization of technological funds managed under a demand-oriented mechanism is that potential beneficiaries lack information ${ }^{12}$.

12 See Casalet, 2003; Jaramillo, 2003; Pacheco, 2003; Vargas Alfaro and Segura Bonilla, 2003; Yoguel, 2003 
The Brazilian system of sectoral technology funds, introduced 1999, overcomes the limits of a purely demand-pull or technology-push incentive scheme. It represents a step forward in regional technology policy design on two accounts: regarding mechanisms to finance S\&T and in terms of operational management. Twelve industrial technological funds are set up through 12 sectoral laws that identify the amount of the income generated in each industrial sector that has to be devoted to support S\&T development in the corresponding industry. Then, these 12 industrial funds collectively contribute to sustain S\&T and R\&D in three priority non industry-specific areas for which three respective funds are built up (cooperation among universities, research centres and enterprises, maintenance and improvement of R\&D infrastructure, and development of S\&T activities in the Amazonian region). The Brazilian sectoral technology fund scheme entails a strategic collective management approach. Representatives of academies and research centres, industrial ministries, members of the Minister for Science and Technology, the business sector and regulatory bodies constitute a mixed management committee that run each technological fund according to a coordinated and consensual strategy. This mechanism, which has the great advantage of promoting coordination and stimulating interaction between private and public sector in technological management, is hard to administer and could originate serious governance troubles which could lead to a sub-utilization of the funds.

In addition to funds there are the fiscal incentive schemes, which essentially take the form of i) tax credits and deductions for different types of R\&D activities according to the categories of involved actors, ii) public development bank loans. Both mechanisms are marginal in terms of use, even though information on fiscal incentive laws is quite easily accessible in many cases. Fiscal incentives are powerful tools to foster selective development of S\&T activities because they allow prioritising in a simple way ${ }^{13}$. Risk capital is an indirect form of fostering science and technology development. Public institutions act as a convoy for private financial resources that flow, through risk capital operations, to business activities consenting to convert technologically advanced projects into operating production entities $^{14}$. Albeit their worldwide-recognized role in favouring technological development, risk capital businesses are hardly found in Latin America and

\footnotetext{
13 In effect they are being used to foster institutional infrastructure development and maintenance, as in the case of Mexico, and to promote patenting related activities as it is happening in Brazil since the year 2002, when tax deductions for enterprises that carry out R\&D activities were doubled if the business units are granted the patent for which they applied for.

14 Risk capital industries are based on private capitals but need public policies to create a favourable environment, to foster liquidity in financial markets, to promote adequate regulatory and incentive systems and to encourage public and private agents involvement in innovation and technological upgrading.
} 
the Caribbean ${ }^{15}$. Scant development of financial markets and institutions and strong uncertainty and volatility of regional macro setting could partly account for the low presence of risk capital operations in Latin America, due to the close linkage existing between this form innovative and risky business support and financial markets.

A rising topic related with S\&T policy is intellectual property (IP) management. There have been several changes in this domain in recent times. On the one hand, there have been changes in international IP management, such as the TRIPS agreement in 1994, and the wave of bilateral free trade agreements (FTA) and bilateral investment treaties (BIT) containing IP provisions $^{16}$. On the other hand, a changing attitude towards patenting and privatization of knowledge emerged. In the US, the Bayh-Dole act of 1980 introduced the possibility for universities to patent discoveries obtained through federal funds ${ }^{17}$. After the adoption of TRIPS most Latin American and Caribbean countries introduced substantial changes in IP regimes. The expansion of the IPRs resulted in the introduction of minimum standards, in the increasing number of patentable products and processes and in the license to import already patented products by means of including this activity under the umbrella of 'sufficient exploitation'.

More recently, countries started to recognize the relevance of IP for their catching up. They have pushed for a change in IP governance, both at the bilateral and multilateral level, rather for a change in terms of organizational behavior of institutions dealing with IP management ${ }^{18}$. Intellectual Property systems are a complex governing arena whose operating mechanisms are not easily manageable. Effective IP management requires proper infrastructure and institutions and actors' preparedness, as well as suitable legal architecture and enforcing mechanisms. Countries need to define their own policy towards patentable subject matter (this is especially relevant in the case of biotechnology and biopharmaceuticals, as for publicly funded research) and they need to develop an IP policy in line with their production and innovation development policy.

\footnotetext{
15 The Argentine Program to support technology base enterprises and risk capital, the Brazilian INOVAR Project and the Risk Capital Portal, the Colombian fund for risk capital investments, the risk capital initiative of the multisectoral investment bank in Salvador and the Mexican capital risk fund for technological development are some regional initiatives in terms of risk capital financing.

16 See Cimoli, Coriat and Primi (2009) for an analysis of recent changes in IP regimes.

17 Beyond the reflection that this provision would foster the dissemination of university research to production, various analysts have raised concerns regarding the drawbacks of the so-called "privatization of scientific activities", which entails rising costs to access basic research results, augmented patenting overheads and amplified risks and costs of legal controversies (Correa, 2003). In reality, the "public nature" of knowledge is definitively shifting towards the private and club goods domain, where access is ruled by given market mechanisms, thus incrementing access barriers to basic research's results.

18 For a critical discussion on the development agenda presented to WIPO see De Beer (2009).
} 
In recent times, another common feature of S\&T policies in the countries of the region is the increasing concern in fostering interaction and coordination between the public sector (mainly universities and research laboratories) and the private sector (essentially enterprises) in research and development. Most financing mechanisms emphasize articulation and co-participation of supply and demand side in technological upgrading, establishing incentive schemes to foster cooperation between them through various channels. Private-public partnership might be a prerequisite for applying for financial support, or additional mechanisms might favour the transfer of capacities between the different agents. An example is the new Brazilian Innovation Law in which greater degree of freedom is given to university researchers for undertaking temporary research at private sector institutions. These initiatives, however, have still to gain strength and economic significance as budgets remain low and practices are still not in accordance with the behaviour of production agents. In effect, partly of the scanty results of these regional S\&T supporting mechanisms, alongside reduced budgets, could be due to the asymmetry between this attention to coordination and the characteristics of regional production specialization. The Latin American and Caribbean production pattern on the one hand, induces private sector and enterprises to express a meagre demand for knowledge, and on the other hand, leads domestic agents to mostly seek outward oriented linkages, privileging foreign companies and research laboratories that already have sound reputation and worldwide recognized experience in effective and efficient S\&T efforts. Thus a mismatch ensues between demand side needs and supply side offerings, hampering policies' impact.

Policies to support the creation of research consortia, science parks and public-private partnership for research have been designed, although seldom implemented, in almost all the countries of the region. ${ }^{19}$ Although this recent shift in the policy model overcomes the drawback of linearity in policy conception, allowing interaction and cooperation between public and private sector, this new model seems to be a kind of 'soft' policy approach. The linkage with sectoral differences and industrial priorities is still missing, and neutrality prevails over selection. Latin America needs to go beyond good intentions in policy formulation and to avoid the typical mismatch between supply and demand in public policy intervention.

The most notable example is the newly launched (May 2008) Brazilian production development policy, which represents the most advanced effort in Latin America in terms of policy design and articulation. The policy is under the general coordination of the Ministry of Development, Industry and Trade

\footnotetext{
19 For a review of policy instruments to support S\&T development by country for Latin America and the Caribbean see the ECLAC-GTZ database, available at www.cepal.org/iyd.
} 
(MDIC). Above this Ministry, there is a consultative body responsible for identifying the policy's main priorities (the National Industrial Development Council, CNDI). This well articulated, although complex, institutional design also considers an executive secretariat composed by the representatives of National Economic and Social Development Bank (BNDES), the Ministry of Finance (MF) and the Brazilian Industrial Development Agency (ABDI). The creation of the executive board responds to the will of reducing institutional bottlenecks that hamper the operation of even well-designed industrial policies, which usually tend to be managed by ministries which are less powerful than institutions in charge of disbursing the financial resources. Ministries in charge of specific issues are responsible for the identification of their strategies and for coordination with the production development policy (the ministry of Science, Technology and Industry, the Ministry of Health, etc.), (Peres and Primi, 2009). This institutional design allows to link science and technology policies to production development, thus allowing for overcoming the chronicle mismatch between policies fostering innovation and policies fostering production.

\section{Central and Eastern Europe ${ }^{20}$}

From the existing scientific and policy analytical literature we can distil two fundamental problems that persist in the innovation systems of CEE countries since a decade if not for a longer period. ${ }^{21}$ First, in most CEE countries there is a long-standing and strong mismatch between R\&D and education system outcomes and industry needs. This mismatch has in turn two mutually enforcing aspects: one the one hand, innovation policies in CEE tend to focus on high technology (for instance, commercialization of $R \& D$ results, technology parks, incubators, etc); on the other hand, actual economic and industrial structure is characterized by low productivity growth and dominated by outsourcing activities with very low demand for R\&D or indeed for most outcomes targeted by innovation policies. Second, in most CEE countries innovation policies suffer from double fragmentation: on the one hand, there is a strong fragmentation and divide between various actors in the innovation system (universities, companies, and governments); on the other hand, also within the public sector fragmentation between various policy areas (education, industry, energy etc) is strong. Such double fragmentation leads to massive and systematic coordination failures in policy design, implementation and evaluation. Clearly, the two challenges are connected and enforcing each

\footnotetext{
20 This sub-section builds on Kattel, Reinert and Suurna, 2009, and Karo and Kattel, 2009.

21 See for detailed country overviews European Commission's Innovation Trend-Chart, 2006 and 2007; see also Radosevic, 2004 and 2006; Reid and Peter, 2008; and Kattel, Reinert and Suurna, 2009. Best research on the CEE innovation systems from the late 1990s also covers the earlier transition period, see in particular Radosevic, 1998 and 1999.
} 
other. In this section, however, we intend to show how these challenges originate from the application of Washington Consensus policy toolbox to CEE economies and while the European Union recognized and emphasised these problems throughout the accession talks and during the negotiations for implementation of EU's structural funding in 2000s, EU's influence has, perversely, enforced or even deepened these challenges. At the same time, EU's influence is a clear step towards much more coherent innovation policies in CEE. In addition, there are also success cases, for instance Slovenia has followed from the outset a rather different approach to innovation policy strongly focused on local capacity building, (Drahokoupil, 2007).

\section{Restructuring Soviet R\&D system and industry}

At the end of the 1980s, Eastern European and former Soviet economies were generally highly industrialized and many of these economies were seemingly on a similar industrialization and growth path as the East Asian economies. According to the World Bank data, countries like Estonia, Latvia and Hungary were ahead of Korea in the early 1980s in terms of industrial value added per capita. (World Bank WDI online database) However, the industrialization of CEE countries was widely understood to be highly artificial and ineffective, using in other words excessive amounts of resources and other inputs to produce goods. Thus, after regaining the independence, restructuring the economy and in particular the industry was on top of the agenda for all CEE countries. In fact, in many ways what was desired was not so much restructuring as outright replacement of old Soviet industry with one similar to the Western industries.

Washington Consensus policies offered a very coherent and relatively simple set of policies to deliver the restructuring and replacement. While all CEE countries set out to implement reforms inspired by the Washington Consensus, Drahokoupil $(2007,90)$ offers a very interesting way how to group different strategies followed by CEE countries in 1990s: "The competition states in the Visegrád four can be called Porterian, aiming at attracting strategic FDI through targeted subsidies ... The Baltic competition states can be called macroeconomic stability-driven neoliberal states with monetary institutions at their core. ... Finally, Slovenia has developed a distinct type of competition state, which can be characterized as a balanced neocorporatist." However, as Weissenbacher $(2007,71)$ argues, Hungary, Poland and Yugoslavia had experiences of dealing with IMF already during 1980 s when they borrowed from it and applied standard austerity programs. Thus, while there are clearly differences in accents, the general framework offered by Washington Consensus was applied in all CEE countries throughout the 1990s and indeed the policy sets were actually converging during the 1990s, (Drahokoupil, 2007). 
Furthermore, Washington Consensus inspired policies were considered by most CEE countries as the innovation and industrial policy measures and in essence there were no other policy initiatives during 1990s. During this period, almost all of economic policy capacity building was directed towards macro-economic competencies (at central banks, ministries of finance, also think tanks). This was greatly helped by the advice and assistance from the Washington institutions such the World Bank and IMF, but also from OECD. Innovation policy was considered as secondary to transition related concerns. As there were no innovation policies proper, there was also essentially no institution building for or in the innovation systems. Washington Consensus inspired policies were understood to deliver the economic stability to attract foreign direct investments that should become vehicles of delivering actual restructuring and replacement of Soviet industry. In other words, market demand was understood to deliver economic restructuring and along with it create also a need and direction for innovation system reform (R\&D, education systems, labour policy etc). Building up capacity in specific areas of innovation systems seemed superfluous; indeed, R\&D system was seen in many ways as too big (employing too many people) and ineffective (too far from the private sector). (Radosevic, 1998 and 1999 offer good overviews)

In reality, the Washington Consensus policies were even too effective in destroying the old industrial structure. After the fall of the Berlin Wall, most CEE and other former Soviet economies saw deep dives in their growth rates and in industry as well as service sector value added. It took more than a decade for most CEE countries to reach the growth and development levels of 1990 (see further Tiits et al., 2008). This is particularly so in the case of former Soviet republics. According the World Bank's (2006) calculations, the recession many former Soviet republics (e.g., Ukraine) experienced during 1990s, and are still experiencing, is worse than the Great Depression in the USA and the World War II in Western Europe (in both cases, recovery was considerably quicker).

This cognitive dissonance between promise of reforms and actual developments was caused by one of the most striking features of post-Soviet development in the 1990s: the rapid primitivization of industrial enterprises or even the outright destruction of many previously well-known and successful companies. This happened because of the way Soviet industrial companies were built up and ran in a complex web of planning and competition. (Radosevic, 1998) A sudden opening of the markets and abolition of capital controls made these industrial companies extremely vulnerable. The partially extreme vertical integration that was the norm in such companies meant that if one part of the value chain ran into problems due to the rapid liberalization, it easily brought down the entire chain or complex. However, foreign companies seeking to privatize plants were almost always interest- 
ed in only part of the value-chain (a specific production plant, infrastructure or location) and thus privatization turned into publicly led attrition of companies and jobs (see, e.g., Frost and Weinstein, 1998; Young, 1994).

Such a drastic change made it relatively easy to actually replace Soviet industry: with the macroeconomic stability and liberalization of markets, followed by a rapid drop in wages, many former Soviet economies became increasingly attractive as privatization targets and destinations for outsourcing of production. Indeed, one of the most fundamental characteristics of CEE industry (and services) since 1990 has been that the majority of companies have engaged in process innovation (i.e., in the form of acquisition of new machinery and mastery of production capabilities) in seeking to become more and more cost-effective in the new market place. (Tiits et al., 2008)

Perversely mirroring the above-described 'cluster'-like characteristic of Soviet industrial activities, the Soviet R\&D system was based on similar vertical integration of R\&D into specialized institutions: "Under socialism, most technical change was pushed from one institutional sector ... which was essentially a grouping of R\&D institutes and other related activities ... This sector involved in activities far beyond R\&D including design, engineering and often trouble-shooting activities." (Radosevic, 1999, 282) These institutions were usually also the originators and carriers of patents and forms of intellectual property rights. (Ibid., 285) This means that the Soviet-style R\&D system had very low level of company in house R\&D. (Radosevic, 1998, 80-81) Industrial conglomerates were effectively cut off from various potential learning and feedback loops; production and actual innovation (in particular in form of new products and processes) took place in different institutions, both however highly concentrated and integrated. Thus, in general the system was highly linear and supply based.

The once complex engineering, designing or similar tasks were in the transition processes very rapidly replaced by significantly more simpler commodified support activities as many companies were wiped out, privatized or restructured. The former R\&D institutes could have played key role in bridging academic research with industry needs as they were essentially the only existing link between the two. With the collapse of the institutes system, the link between academy-industry became, as Radosevic suspected in 1998, the weakest link in the CEE R\&D system. $(1998,90)$ Indeed, in "conditions of high uncertainty and prolonged privatization, the intangible assets and know-how of industrial institutes, primarily embodied in R\&D groups, probably erodes much faster than production skills in industry." (1998, 100) 
Massive onslaught of FDI, in particular since the second half of 1990s and privatization of enterprises gave foreign enterprises key role in industrial restructuring and innovation. This, in turn, only reinforced severing of linkages between former $R \& D$ institutes and enterprise sector. (See also Radosevic, 1999, 297)

Thus, we can sum up the key features of CEE innovation systems before the accession into the EU as follows:

- Privatization programs and other measures to attract foreign direct investments;

- Emphasis on macro-economic stability;

- Erosion and partial disintegration of the previous Soviet R\&D system;

- Market demand as key force of restructuring and reform of innovation system.

\section{Europeanization of innovation policy in CEE since 1998}

While EU's importance for CEE countries economic policies was visible already during early 1990s, the change that increased EU's impact considerably was the beginning of accession talks with most CEE countries in 1998 and later. Indeed, Havlik et al. (2001) argue that the adoption of the EU's acquis communautaire has had a much stronger impact on the modernization of CEE industry than official (often rudimentary) innovation policy during 1990s. The introduction of new regulation (usually with significantly higher safety, health and other standards) meant that CEE industry "was forced to choose whether to modernize their products and production facilities rather drastically, to subject themselves to mergers with bigger players with greater economies of scale, or to close down altogether". (Tiits et al., 2008, 76-77) In essence, on the one hand, the harmonization process was a continuation of restructuring processes that started during the previous period and were even significantly enforced. On the other hand, through socalled pre-structural funding and its management, many CEE countries started to develop first strategic documents and policies related to innovation and R\&D proper. In this sense the EU integration played enormously positive roll on all CEE countries and their innovation policies.

However, similarly to Washington Consensus inspired reforms in 1990s, harmonization process was seen largely as a further legitimization of CEE's path. Thus, the end itself - accession to the EU - became much more important than what and how was being harmonized. Due to considerable self-imposed time pressure - harmonizing the legal infrastructure and 
preparing for accession in 6 years - meant that adoption of EU's legal infrastructure was done hastily and without much attention to local context. (PHARE Consolidated Summary Report, 2004 and 2007; see also Schimmelfennig and Sedelmeier, 2004; Goetz, 2001).

There were two main vehicles of harmonization: PHARE funding mechanism and later pre-structural funding. PHARE was launched in 1989 as EU's financial instrument to assist the CEE countries (initially only Hungary and Poland) in their political and economic transition from a centralised communist system to a decentralised liberal democratic system. In the late 1990s, due to the progressive decentralization of the PHARE management structures as well as EU requirement for creation of regional and local institutions to administer the EU funds after the accession, a system of implementation agencies/administrative agents linked to the National Funds was created and pursued in CEE (Commission Decision on the Review of the PHARE Guidelines for the period 2000-2006; Grabbe, 2006, 82). This marks the first step in CEE towards managing economic policy, and thus innovation and industrial restructuring in a distinctly different manner from the previous period where the free market and external forces were seen as key drivers of change. However, it is also important to see that these newly established agencies are mostly for managing external funding, policy creation and respective capacity building plays almost no role in these agencies. The compartmentalized and structured nature of EU support (PHARE Consolidated Summary Report, 2007) on the one hand, and from the 1990s inherited lack of tradition of partnership and inter-institutional coordination and cooperation between administrative levels on the other hand, meant that most positive effects of such agencies were not reaped and that they created in some cases more difficulties and problems than they solved (ESPON, 2005).

In sum, in many ways the harmonization with the EU rules is a period where policies supported the restructuring of the industry that began in 1990s under the Washington Consensus policies; on the other hand, during this period EU's influence on funding and administrative schemes brought creation of novel governance structures that play up to today key part in innovation policy in CEE.

While harmonization with the EU legal infrastructure was important both in terms of actual changes it brought to industry and in terms of policy implementation/administrative agencies that were created to manage EU's financial help, the key changes in innovation policy proper came with EU structural funding ${ }^{22}$ that started in 2004 and is set to continue at least until

\footnotetext{
22 For a general overview, see the EU's official homepage for structural funding, http://ec.europa. eu/regional_policy/funds/prord/sf_en.htm.
} 
2013. Indeed, as we will see below, the EU structural funding significantly changed both the policy content and implementation. However, as we will also see below, key problems that emerged during 1990s (low networking, weak coordination and significant cooperation problems) have been in fact deepened during the current period.

The key content for many innovation policy initiatives in CEE emerging after the accession was the underlying assumption that similarly to 'old' European countries, also the new members need to overcome the so-called 'European paradox' (good basic research, low commercialization of the research results). ${ }^{23}$ Thus, CEE innovation policies emerging in early and mid 2000 s tend to concentrate on high technology sectors, on commercializing university research, technology parks for start-ups and similar efforts. (Radosevic, 2002, 355; Radosevic and Reid, 2006, 297; also INNO-Policy TrendChart Country Reports, 2006 and 2007 for comprehensive overviews of CEE countries' policies and challenges) In contents, overwhelming number of policy measures concentrate upon innovation programmes and technology platforms. (Reid and Peter, 2008) At the same time, the CEE emerging innovation policies are characterized by their horizontal nature: policy measures typically do not specify sectors but are rather open too all sectors. Arguably, this has to do with they way CEE policy makers understood EU state aid regulations (Reid and Peter, 2008). We argue that this has to do with both general neo-liberal outlook inherited from the 1990s (i.e., market demand is seen as key driver for R\&D system) internalized by most CEE policy makers by early 2000 s and also their particular skills that concentrated into macro-economic area. (See also Drahokoupil, 2007)

In addition, as majority of CEE measures are financed through EU structural funds, these instruments are mostly competition and project based. These aspects - project based implementation, multitude of horizontal measures - point to high fragmentation of the entire innovation policy field as well as to lack of policy priorities or the ability to set the latter. It is also evidence of the strongly market-driven understanding of innovation that is at odds with underlying assumption that innovation policies need to alleviate the 'European paradox'. That is, typical CEE innovation policy measure aims to commercialize a certain $R \& D$ result, typically in an high-tech area, but the result and thus the initiative has to come from the market. This, however, has scarcely any justifications in reality: first, CEE R\&D systems and their performance disintegrated heavily during 1990s; second, this was complemented by the strong specialization into low-end of various valuechains meaning that the demand for $R \& D$ and skills remain relatively low.

23 An excellent discussion of the paradox is Dosi, Llerena and Labini 2005. 
In terms of implementation, the trend initiated during the harmonization period through creation of financial and management agencies has been intensified with the structural funds. (See INNO-Policy TrendChart Country Reports, 2006 and 2007 for an overview) It is fair to say that the problems with these agencies that started during the harmonization period are partially deepened since 2004. Indeed, it can be argued that most problems summarized above in CEE innovation policies, go in one way or other back to the institutional framework of agencies. Almost all CEE innovation policy implementation problems go back to very weak and disorganised actors, coordination problems are rampant in policy design and implementation (see also Radosevic, 2002, 355). On the one hand, there is a clear separation of policy responsibility between education/science and innovation/industry on the ministerial level and its delivery system (Nauwelaers and Reid, 2002, 365; also see INNO-Policy TrendChart Country Reports, 2006 and 2007). On the other hand, this kind of fragmented policy-making system has in its turn resulted in the lack of inter-linking and cooperation between different innovation-related activities and actors such as research organisations, government and industry (see INNO-Policy TrendChart Country Reports, 2006 and 2007).

Thus, to sum up, while with the introduction of structural funds and through strong influence from the European Commission, CEE innovation policies are significantly changing since mid-2000s, there are also serious problems that emerged with this trend. First, as we argued, the emerging innovation policies tend to be based on rather linear understanding of innovation (from lab to market) whereas most CEE countries are specialized into low end production activities virtually void of any research and with low demand for high skills; in addition, R\&D system as such has been under constant pressure since the transition and its performance has been clearly lacking. Thus, CEE innovation policies tend solve problems not existing in the respective economies and in this context the problem of misunderstanding of the Soviet $R \& D$ and industry in 1990s is replicated to the policy-making model of the 2000s.

Second, through creation of innovation policy implementation/administrative agencies (for structural funding and beyond), the innovation policy landscape is fragmented and previous problems in policy creation (lack of strategic skills and capacity, networking and coordination non-existent) and implementation (competitive grant-based programming that relies on market signals without being able to follow set priorities and goals) are only deepened. One can argue that the innovation policies emerging in the process of Europeanization are based on the assumption that policy design and implementation follow public-private partnership model, yet in reality CEE countries singularly lack the ability to implement such a model and what is more, 
actual developments in industry seem to suggest that such a model is particularly ill-fitted to CEE context.

In addition, there is an essential problem that CEE economic and innovation policy making ignored throughout 1990s and 2000s in devising policies to deliver economic restructuring and growth. Stable macro-economic environment envisioned to enable FDI inflow - in which CEE were indeed spectacularly successful - also encouraged massive private foreign lending (mostly through foreign banks settling into CEE markets that borrowed in foreign currency). This drove in particular since the mid 2000s consumption and real-estate booms in all CEE countries. (See, e.g., Fitch, 2007a, 2007b and 2007c; see also Krugman, 2008b in this context) Indeed, most CEE countries are highly dependent on foreign investments and private borrowing and thus they were caught in a macroeconomic dead end with appreciating exchange rates, negative current account balances and growing private indebtedness. This led to increased financial fragility through deteriorating balance of payments account and left CEE countries starving for new foreign lending and investments that however stopped in the aftermath of the global financial meltdown in 2008. In essence, CEE industrial restructuring and innovation model became a giant Ponzi scheme. As global, and especially inner-EU demand slows, so do CEE exports and by early 2009 most CEE currencies have seen massive drops in their value and foreign investors seem to flee en masse. Debt deflation looks very likely scenario for the coming years. Fragmented innovation policy scene, inherited from the accession into the EU, paralyses CEE countries into inaction as there seems to be no serious policy evaluation capacity present and coordination problems prevent quick reaction to radically changed environment.

Thus, we can sum up the influence of the EU upon CEE innovation systems as follows:

- Much more active role of the state in structural and innovation policies;

- Policies concentrate on commercialization and other R\&D aspects; high technology bias certified;

- Increasing fragmentation of policy arena through agencies that results in strong coordination problems;

- Growing mismatch between R\&D system, high-tech biased innovation policy and actual industry needs. 


\section{Policy models in a comparative perspective}

It is possible to identify three main phases in the evolution of innovation policy in LA and CEE (see Table 2). During the import substitution in LA and the Soviet administration in CEE linear supply policy regime prevailed. The state was actively involved in the generation of the basic scientific and technological infrastructure (national research institutes and public research laboratories in strategic areas), as a support to the generation of production capacities in sectors such as mechanical, nuclear, transport and telecommunication. The linear supply model implicitly assumed that scientific progress would automatically turn into technological innovation. Policy measures were selective in terms of targeted sectors and the provision of knowledge was centralized and basically in the hand of public laboratories. S\&T policies were a component of the industrialization strategy and ultimately supported the creation of basic capabilities for supporting production in key strategic sectors. The model was not perfect in itself, as all models are not; but it served the purpose of creating the institutional infrastructure and the basic capabilities for the transition towards industrialization. Some drawbacks of the model were the lack of coordination between different activities and the lack of mechanisms for avoiding the capture of rents by incumbents.

In the decade of the 1990s both regions followed the Washington Consensus and embraced a series of market-led reforms. However, while it was sure that reforms were needed in the management of policies to support production development and the accumulation of technological capabilities, the obsession with macroeconomic stability led to marginalization of policies directed to microeconomic behaviour. Reforms to the previous linear supply model were needed, however the change in policy model induced by the Washington Consensus failed to target and correct the shortcomings of the previous model; instead they introduced a radical shift in policy model. State intervention was minimized, and a linear demand oriented policy regime was introduced. The market logic ruled the innovation policy discourse, and the private sector was seen as the primary repository of knowledge and innovation capabilities. Getting the framework conditions right, simplifying mechanisms for technology transfer (especially NorthSouth in the case of LA) and establishing funds and credits for innovating firms were the mostly accepted policy tools. The reforms favoured modernization of production apparatus through rising capital imports and FDI; however, in the case of LA the modernization strengthened already established actors and did not trickled down to the rest of the production apparatus; in the case of CEE, the reforms led to fast and furious replacement of Soviet industry with low value-added outsourcing production. In addition, the reforms delinked the efforts for strengthening S\&T capabilities from the industrialization effort. Implicitly, S\&T started to be considered as 'neutral' 
and the policy regime turned into a demand oriented one, with stimulus packages for innovation and technological upgrading offered through open calls to firms.

One of the drawbacks of that policy model was the persistent linearity in addressing innovation; in addition, the countries of the regions would have required policies supporting industrialization and the creation of production capacities together with the support for innovation, instead of importing good practices from the 'north' which however had little impact in a context in which the demand for innovation from domestic agents was scant due to structural conditions.

Slowly, while the market-led approach showed its limits in the capacity to support catching up and technical change, and in line with changes in policy attitude in frontier countries, both LA and CEE entered in a post Washington Consensus phase, which for CEE has been marked by the process of accession to the EU. In those years a new language became to be adopted by the innovation policy community and a systemic approached prevailed. Public-private partnerships and cooperation between the agents of the national innovation system were advocated as the main drivers for innovation. Multidisciplinariety was included as a key driver for fostering the generation and application of new ideas and efforts to design policies through a participatory approach were developed. Clearly, the transition to a non linear policy model which recognizes the systemic dimension of innovation represents a positive step, however, the reform failed to address the main problem posed by the previous generation of reforms: the detachment between innovation and industrial structure. In essence, both LA and CEE countries have experienced in past two decades a 'stop-and-go' evolution in innovation policy: each new policy model has tried to target problems inherited from previous policy generation but has mostly failed to do so and in fact created additional problems in policy implementation and coordination. This leads to what we call periphery paradox in innovation policy: despite growing importance given to innovation policy in LA and CEE economies, actual policy capacity and policy effectiveness does not rise accordingly. One of the explanations we adduce, in the evolution of the political economy of innovation policy in the 'periphery', is the missing link between the production side and the innovation policy.

The financial crisis urged countries to redefine priorities and investment strategies; it also let countries to face key production challenges such as social and environmental sustainability of current consumption and production patterns. Advanced countries deepened the debate on which types of innovation they should foster and through which mechanisms. A shift towards a greener, fairer and more oriented to knowledge circulation and diffusion policy agenda seems to be forthcoming. Peripheral regions will 
probably face the same transition; however, they should avoid pursuing this spiral of moving the innovation policy target without solving the problems by previous policy efforts. Policy learning proceeds through trials and errors, but errors need to be identified and corrected in order to engender a virtuous policy process. Overcoming the current mismatch between innovation policy and production development is a must for peripheral regions. There are no blue prints for linking back innovation policies with an industrialization strategy aiming at creating domestic capabilities in key sector; each country should identify how to do it and through which institutions and mechanisms. A regional dialogue could support this process and ease the transfer of good practices and experiences between countries.

Table 2. EVOLUTION OF INNOVATION POLICY MODELS IN LA AND CEE: A COMPARATIVE PERSPECTIVE

\begin{tabular}{|c|c|c|c|c|}
\hline Period & $\begin{array}{l}\text { LA: Import } \\
\text { substitution } \\
\text { CEE: Soviet } \\
\text { system }\end{array}$ & $\begin{array}{l}\text { Washington } \\
\text { Consensus }\end{array}$ & $\begin{array}{l}\text { LA: Post-Washington } \\
\text { consensus } \\
\text { CEE: Accession } \\
\text { to the EU }\end{array}$ & $\begin{array}{l}\text { Post 2008-09 } \\
\text { Financial Crisis }\end{array}$ \\
\hline $\begin{array}{l}\text { Policy } \\
\text { regime }\end{array}$ & $\begin{array}{l}\text { Linear Supply } \\
\text { model }\end{array}$ & $\begin{array}{l}\text { Linear demand } \\
\text { model }\end{array}$ & $\begin{array}{l}\text { Public-private } \\
\text { partnership model }\end{array}$ & \multirow{5}{*}{$\begin{array}{l}\text { Towards a new } \\
\text { policy model? }\end{array}$} \\
\hline $\begin{array}{l}\text { Main } \\
\text { perspective }\end{array}$ & $\begin{array}{l}\text { Public sector } \\
\text { as main S\&T } \\
\text { provider }\end{array}$ & $\begin{array}{l}\text { Private sector } \\
\text { as main source } \\
\text { of } T \& l\end{array}$ & $\begin{array}{l}\text { Public-private partner- } \\
\text { ship as main source } \\
\text { of knowledge and } \\
\text { technology transfer }\end{array}$ & \\
\hline $\begin{array}{l}\text { Pattern of } \\
\text { knowledge } \\
\text { diffusion }\end{array}$ & $\begin{array}{l}\text { Hierarchical: } \\
\text { top-down }\end{array}$ & $\begin{array}{l}\text { Hierarchical: } \\
\text { bottom-up }\end{array}$ & Systemic & \\
\hline $\begin{array}{l}\text { Main policy } \\
\text { measures }\end{array}$ & $\begin{array}{l}\text { Selective and } \\
\text { centralized } \\
\text { supply S\&T } \\
\text { policies }\end{array}$ & $\begin{array}{l}\text { Horizontal and } \\
\text { demand-oriented } \\
\text { innovation poli- } \\
\text { cies + technology } \\
\text { transfer via FDI }\end{array}$ & $\begin{array}{l}\text { Public private } \\
\text { partnership and } \\
\text { multidisciplinary- } \\
\text { oriented T\&I policies }\end{array}$ & \\
\hline $\begin{array}{l}\text { Managemen } \\
t \text { criteria } \\
\text { of S\&T } \\
\text { institutions }\end{array}$ & $\begin{array}{l}\text { Predominance } \\
\text { of criteria } \\
\text { coming from } \\
\text { the scientific } \\
\text { community and } \\
\text { the state-owned } \\
\text { companies }\end{array}$ & $\begin{array}{l}\text { Predominance of } \\
\text { private sector } \\
\text { and market } \\
\text { mechanisms }\end{array}$ & $\begin{array}{l}\text { Increasing orientation } \\
\text { towards participatory } \\
\text { approach in policy } \\
\text { management and } \\
\text { creation of agencies } \\
\text { fostering public-private } \\
\text { interaction }\end{array}$ & \\
\hline
\end{tabular}

Source: own elaboration based on Cimoli, Ferraz and Primi, 2005 and Kattel, Reinert and Suurna, 2009. 
While in frontier countries there are already industrial constituencies lobbing for innovation policy, developing countries still face the challenge of building production capacities which will represent the targeted audience of the innovation policy, and in addition they need to respond to the global demand (pressure) coming from foreign companies operating in peripheral countries. Innovation policy is not a neutral policy, it is a policy with strong sectoral components, and in developing economies this means that it needs to be coupled with policies supporting production development. It is in this mismatch between the production structure specialization and the innovation policy discourse that we identify a similarity between LA and CEE, beyond the innovation 'failure' versus 'success' vision. Both regions need to increase productivity, employment and well-being and a modification in the prevailing specialization pattern towards more knowledge intensive activities coupled with modernization of average production techniques and organization is needed.

A generalized call for innovation, detached from policies supporting structural change and the creation of domestic production and scientific capabilities, will not suffice. Currently, LA and CEE both suffer from the 'periphery paradox' in innovation policy; i.e. rising political attention towards innovation detached from efforts devoted to strengthen the actors (firms, universities, institutions) which demand and offer the knowledge required for innovation. The detachment of the innovation policy from the dynamics of the real economy is particularly dangerous in peripheral countries which need to create a consensus for supporting innovation policies. Supporting innovation without creating and strengthening the actors which should innovate is a costly mistake, not only in budgetary terms, but because this attitude contributes to delegitimize policies augmenting the impression that 'policies do not work'. And, in fact they do not work, or they have a reduced impact because most of the time, for well designed they are, they address a missing actor. This happened, especially in the case of technology transfer policies and the policies supporting patenting activities. In contexts where firms carry out basically incremental innovations and modernization of production, a policy fostering patenting basically misses its target: a firm for which patenting could be a good corporate strategy. Hence, those policies should be a support and should be ancillaries to policies fostering the creation of innovative production agents.

\section{The 'pro-innovation' momentum: a way out from the periphery paradox?}

After the 1990s, the decade in which 'no policy' was the best policy, innovation policies are back on the development agenda in Latin America as well as in Central and Easter Europe. The political conjuncture of the last years 
has been particularly favorable to innovation, at least at the rhetorical level. However, countries face serious barriers in implementing policies and in matching innovation with structural change and industrialization.

The financial crisis led frontier countries to prioritize innovation as a way out from the crisis. In peripheral economies - which were in the process of creating endogenous technological and production capabilities - short term competitive pressures would lead firms to reduce investments in R\&D and in risky and uncertain innovations. This reduces the technological base with which those economies will face the post-crisis scenario. A sort of lock-in process emerges, in which countries which should invest the most in supporting the creation of endogenous technological capabilities are led to invest less as a result of short term pressures. Redefining S\&T priorities as a response to the crisis in an optic of short term would reinforce peripheral marginal position in the global economy. A proactive response is needed. However, responding to the crisis it is easier said than done. Re-adaptation and change are costly, and require time and resources. The speed, and the direction of change, with which the firm responds to the shock it is crucial to remain competitive in the market. And, obviously, not all firms will be able to respond swiftly enough. The effects of the re-adaptation of capabilities and production and investment strategies on productivity will not be immediate. There will be a time-lag, and during this time, the economy will necessarily experience a slowdown in productivity growth. Clearly, the time for re-adaptation depends on many factors, such as the specificities of the assets of firms, the kind of routines in the firm's management strategy and the general characteristics of the human capital - i.e. there is some degree of stickiness in technological and production capacities of firms which determines the time and direction of the re-adaptation process. A smart policy mix can support a smooth transition.

Research and knowledge capabilities are difficult to reconvert and recover, and the perception that knowledge will be the assets that will determine the repositioning of powers in the post crisis, justify maintaining investments in those assets even in a crisis scenario. Of course it is not a matter of 'spending for the sake of spending' as might be possible in a 'bonanza' momentum. It is time for a 'smart spending'. But 'smart' in this context is, more than ever, a synonymous for technology, knowledge and intangibles asset, not for cost-effectiveness and efficiency in investment.

However, looking at the crisis as a 'creative destruction' momentum in the current capitalistic development, should not lead to naive stand viewing the crisis as straightforward opportunity. Opportunities will be strictly linked with capabilities in new paradigms and technologies. Countries which master relevant knowledge in the new paradigms, countries that will have the human capital in those areas, countries with big high tech firms, will have an easi- 
er way out of the crisis, than countries which were at the margins of the knowledge game in the pre-crisis scenario. Likewise, there will be windows of opportunities for all, but they will be understood and possibly profited only by firms (and countries) which follow a knowledge-centred development strategy and which will prioritize the construction of scientific and technological capabilities also in this crisis context. It is highly probable that in the future the basis for competitiveness of firms will be largely redefined. New demands will ensue, and probably there will be a redefinition of production with a shift of priorities towards environmental sustainability and welfare concerns, rather than on the tecological race of past years.

The current financial crisis and the non-deferrable challenges of climate change, energy and sustainability of production revitalized the debate of the role of the state in the economy in advanced economies. There is a rising interest in new forms of innovation which should better respond to citizen's needs and increasingly respect the environment and an efficient use of energies and resources. A window of opportunity opens for LA and CEE to support innovation and elaborate policy models which overcome the bottlenecks of current situation. However, profiting from the reorganization of powers and equilibria which will result after the crisis will not happen through market forces alone. The (sometimes) oversimplified innovation discourse of last years has led to the elaboration of national plans which are seldom or partially implemented, but which have at least generated certain institutional learning in terms of policy management. Efforts should be tailored to implementation and effective support to production development.

The current 'pro-innovation' momentum - at the regional and the global level - represents an opportunity to capitalize on past experiences and to overcome some of the limits of the previous science and technology policy models.

A lesson that can be learned is that policies modify agents' behavior through incentives which then needs to be incorporated into policy design in order to adapt policies to the new scenario. Also, policies require institution for their management and implementation and introducing new policies requires analyzing which kind of institutional set up will support the policy implementation and identify the adjustment mechanism needed to support the translation of policy design to implementation.

Learning, path dependency and cumulativeness affect the dynamics of policies and they should be taken into account when introducing reforms. Actually, both in LA and in CEE there are success stories of policy evolution which avoided to be trapped in the 'stop-and-go' cycle of continuous reforms addressing only partially the shortcomings of a model, and engendering new problems which then needed to be solved by a new reform. 
Brazil, for example, is a success case in this respect. The various political administrations supported the generation of scientific and technological capabilities with certain continuity, allowing the country to capitalize on previous experiences in policy design and management. The dynamic of innovation policy followed a more cumulative approach rather than a 'stop-and-go' and, in the last years there have been several efforts to design comprehensive policies which link innovation capacities to production development. The PICTE (Industrial, Technology and Trade Policy) launched in 2004 represented the first return of industrial policies in the agenda and it institutionalized the need to look at technology policies in the frame of a more complex policy mix; the Production Development Policy launched in 2008 capitalizes on the previous experience, and goes further in elaborating a policy mix which articulates support to industries with the need to create capacities in key strategic sectors. Innovation is not 'neutral' in the current Brazilian policy; innovation is search for and supported in given sectors and according to strategic priorities. This of course, requires negotiations between actors and strong capabilities in policy management in order to move from policy design to implementation.

In $\mathrm{CEE}$, the European Union has had enormous influence in redirecting CEE countries' attention to industrial upgrading and some countries have been exemplary in building policies that correspond to industry needs, for instance Slovenia. While Slovenia has been able to focus innovation policies towards upgrading existing industry and skills from the early on in 1990s, it serves as an exception not as a rule of CEE developments. Indeed, it can be argued that there are strong historical reasons for Slovenia's success (e.g. partial private property prior to independence) that are not replicable in the other CEE countries.

Policy capacities are built over time through a cumulative process, just as scientific, technological and innovation capacities. There are multiple policy approaches and models, some better fit in certain contexts, others they are more appropriate for more advanced countries, however it is not the 'best policy model' that should be searched for, but a possible policy regime which taking into account the starting point of policy management capacities and production structure will better respond to the need of fostering innovation and structural change. Policy fine tuning is probably more desirable than a radical shift in prevailing policy approach which will undermine the process of policy learning and accumulation of capacities.

\section{Conclusions}

There are no generic blue prints for an optimal technology policy. Policy goals, instruments and capabilities must be tailored to country specific context and time requirements and they have to cope with local financial con- 
straints. The mix of suitable policies should take into account regional specificities and should be designed on the basis of a renewed and more pragmatic technology policy model which needs new institutional settings for policy management and implementation.

Disposing of a well designed policy is not a sufficient guarantee. A key factor of success for any technology policy is the matching of its goals with production structure needs and effective demand. Path dependent and cumulative processes form key features of policy processes that should be taken into account while devising new or revising existing initiatives. The design and implementation of innovation policies requires mechanisms for policy follow up. Establishing mechanisms for identifying success and failure factors in policy implementation and the creation of institutional mechanisms for fine tuning policy accordingly are required.

The process of construction of capabilities for innovation is costly, in terms of the necessary time, resources and institutional experiments. While it is normal to progress along this track by trial and error, it has to be recognized that errors are not always easily reversible. Identifying factors which engender failures in the process of policy design and implementation matters for improving the capacity to develop new policy solutions which actually better respond to the challenges posed by the changing context and nature of innovation, but which limit the generation of 'new problems' which will need new policies to deal with. Usually a policy, whether 'good' or 'bad' will engender changes in the scenario and in the agents' responses, and probability new or modified policies will be needed to deal with the reshaped scenario. However, while advanced countries usually concentrate their policy efforts in identifying new trends for implementing policies which are able to deal with those trends and which ultimate goal is to support the country's competitiveness and well-being, in the periphery it happens that the policy dynamic tends to be trapped by a sort of Red-Queen effect ("Now, here, you see, it takes all the running you can do to keep in the same place ${ }^{24}$ ), where new policies are introduced, basically following foreign good practices, seldom implemented and with scant impacts due to the mismatch with the demand side, thus engendering a 'periphery paradox'. As it was argued, and then dismissed, that Europe was suffering from a paradox, i.e. a region characterized by excellence in research and poor capacity to translate into production those research outcomes, the periphery seems to suffer form a paradox in which innovation is in countries' development agendas, but the moving target addressed by policies in the last decades has been dominated by a 'new problem - new policy solution' approach rather than on incremental efforts for building endogenous capabilities.

24 Carrol, L. 1872. Through the looking glass and what Alice found there. Macmillan, London. 


\section{References}

Amsden, A. (1989), Asia's next giant: Soth Korea and the last industrialization, New York, Oxford University Press

Burlamaqui, Leonardo, Jose A. P. de Souza and Nelson H. Barbosa-Filho. 2007. "The rise and halt of economic development in Brazil, 19452004: Industrial catching-up, institutional innovation, and financial fragility." In Ha-Joon Chang, ed., Institutional Change and Economic Development. London: Anthem, 239-259.

Capdevielle, M., M. Casalet and Mario Cimoli (2000). "Sistema de innovación: el caso mexicano", Proyecto Instituciones y mercados, Comisión Económica para América Latina y el Caribe (CEPAL)/Sociedad Alemana de Cooperación Técnica (GTZ).

Capdeville, M., Cimoli, M. and Casalet, M. (2000), Sistema de innovación: el caso Méxicano, Proyecto Instituciones y Mercados, CEPAL/GTZ

Casalet, M. (2003), Políticas científicasy tecnológicas en México: evaluación e impacto, FLACSo México

Cimoli, M., Ferraz, J C, Primi, A. (2005). Science and Technology Policies in Open Economies: The Case of Latin America And the Caribbean. Santiago: ECLAC.

Cimoli, Mario and Annalisa Primi (2004). “Las políticas tecnológicas para la creación y difusión del conocimiento en América Latina y el Caribe", mimeo, División de Desarrollo Productivo y Empresarial, CEPAL.

Cimoli, M., Coriat, B. and Primi, A. (2009), Intellectual property and industrial development a critical assessment, in Cimoli, M., Dosi, G. and Stiglitz, J. E. (eds) (2009), The political economy of capabilities accumulation: the past and future of industrial policies for development, Oxford University Press

Cimoli, M., M. Holland, G. Porcile, A. Primi, S. Vergara (2006), Growth, Structural Change and Technological Capabilities: Latina America in a Comparative Perspective, LEM Working Paper Series, 2006/11

De Beer, J. (ed) (2009), Implementing the World Intellectual Property Organization's Development Agenda, Laurier University Press, Canada

Dosi, Giovanni, Patrick Llerena and Mauro Sylos Labini (2005). “Science Technology-Industry Links and the 'European Paradox': Some Notes on the Dynamics of Scientific and Technological Research in Europe", LEM Working Paper Series 2005/2, available at http:// www.lem.sssup.it/WPLem/files/2005-02.pdf.

Drahokoupil, Jan (2007). "From National Capitalisms to Foreign-Led Growth: The Moment of Convergence in Central and Eastern Europe", in Becker and Weissenbacher 2007, pp. 87-108.

ECLAC (2004). Productive development in open economies, LC/G.2234 (SES.30/3), Santiago, Chile. 
ECLAC (2008), Structural change and productivity growth: 20 years later: old problems, new opportunities, ECLAC-United Nations, Santiago, Chile

ECLAC (2008b), La economía del Conocimiento, Espacios Iberoamericanos, Naciones Unidas, CEPAL (Comisión Económica para América Latina y el Caribe)/ SEGIB (Secretaría General Iberoamericana)Santiago, Chile

Correa, M. (2003), "Políticas para Propiedad Intelectual", documentos de la "Reunión Regional OMPI- CEPAL de Expertos sobre el Sistema Nacional de Innovación: Propiedad Intelectual, Universidad y Empresa", Santiago, Chile

European Commission (2003). Decision (C) No 4906/2003 of 23 December 2003 on the Review of the Guidelines for Implementation of the Phare Programme in Candidate Countries for the Period 2000-2006, Application of Article 8 of Regulation 3906/89.

Goetz, K. H. (2001). "Making sense of post-communist central administration: Modernization, europeanization or latinization?", Journal of European Public Policy, 8(6), 1032-1051.

Grabbe, H. (2006). The EU's Transformative Power: Europeanization through Conditionality in Central and Eastern Europe. Basingstoke: Palgrave Macmillan.

Jomo, K. S. (1997), Southeas Asia's misunderstood miracle: industrial policy and economic development in Thailand, Malaysia and Inonesia, Westview Press

Fitch (2007a). Risks Rising in the Baltic States? Special report, 6 March.

- - (2007b). Bulgaria, Croatia, Romania - how sustainable are external imbalances? Special report, 20 March.

_- (2007c). The Baltic States: Risks Rising in the Trailblazers of Emerging Europe? Special report, 8 June.

ESPON = Institut für Regionalentwicklung und Strukturplanung (2005). ESPON 2.2.2 Pre-Accession Aid Impact Analysis. Final Report. Germany. Available at: http://www.espon.eu/mmp/online/website/ content/projects/ 243/340/file_653/fr-2.2.2-full.pdf.

Frost, A. and M. Weinstein (1998). "ABB Poland". Richard Ivey School of Business. The University of Ontario.

Havlik, P., M. Landesmann, R. Stehrer, R. Römisch and B. Gilsätter (2001). Competitiveness of industry in CEE candidate countries: Composite paper. WIIW Research Reports, 278. Available at http://www.wiiw. ac.at/news.html.

Hobday, Michael (2009). "Asian Innovation Experiences and Latin American Visions: Exploiting Shifts in Techno-Economic Paradigms", in Drechsler, W., Kattel, R., Reinert, E. (Eds.), Techno-Economic Paradigms: Essays in Honor of Carlota Perez, Anthem, London.

INNO-Policy TrendChart (2006). European Innovation Progress Report 2006. European Communities. Available at http://www.proinno- 
europe.eu/index.cfm? fuseaction $=$ page. display $\&$ topic $I D=264$ \&parentID $=52$.

INNO-Policy TrendChart (2006-2007). INNO-Policy TrendChart Annual Country Reports for Czech Republic, Estonia, Hungary, Latvia, Lithuania, Poland, Slovacia, Slovenia, Bulgaria and Rumenia. Reports for the years of 2006 and 2007 (in some occasions to specify facts reports for earlier years) have been used. European Communities. Available at http://www.proinno-europe.eu/index. $\mathrm{cfm}$ ? fuseaction = page. display \&topic $I D=263 \&$ parent $I D=52$.

Jaramillo Salazar, H., (2003), "Políticas científicas y tecnológicas en Colombia: evaluación e impacto durante la década de los noventa", Trabajo realizado para la CEPAL, Bogotá, Colombia.

Karo, Erkki and Rainer Kattel (2009). “The Copying Paradox: Why Converging Policies but Diverging Capacities for Development in Eastern European Innovation Systems?" The Other Canon and Tallinn University of Technology Working Papers in Technology Governance and Economic Dynamics, 24, forthcoming.

Kattel, Rainer, Erik S Reinert and Margit Suurna (2009). "Industrial Restructuring and Innovation Policy in Central and Eastern Europe since 1990", in M Cimoli, G Dosi and A Primi (eds.), Learning, knowledge and innovation: Policy Challenges for the $21^{\text {st }}$ century, Oxford: Oxford University Press, forthcoming.

Kregel, Jan A (2008). 'The Discrete Charm of the Washington Consensus'. The Levy Economics Institute of Bard College Working Paper No 533. Available at http://www.levy.org/pubs/wp 533.pdf

OECD (2009). The OECD Innovation Strategy: Draft Interim Report. Paris: OECD.

Pacheco, C. (2003). "As reformas da Política Nacional de Ciência Tecnologia e inovaçao no Brasil, 1999- 2002", Trabajo realizado para la CEPAL, Campinas, Brasil.

Peres, W. and Primi, A. (2009), Theory and practice of industrial policy: evidence from the Latin American Experience, Production Development Series, n. 187, ECLAC-United Nations, Santiago

Phare Consolidated Summary report (2004). From Pre-Accession to Accession: Interim Evaluation of Phare Support Allocated in 1992-2002 and Implemented until November 2003, European Commission.

Phare Consolidated Summary report (2007). Supporting Enlargement What Does Evaluation Show? Ex-post Evaluation of Phare Support Allocated between 1999-2001, with Brief Review of Post-2001 Allocations, Consolidated Summary Report 2007. European Commission Directorate-General Enlargement. Available at http://ec. europa.eu/enlargement/pdf/financial_assistance/phare/evaluation/ consolidated_summary_report_phare_ex_post_eval.pdf.

Primi, A. (2009), Regional cooperation in S\&T policies: a view from Latin America, CGEE, Brazil, Rio de Janeiro, International Seminar on "Inter- 
national Cooperation in the Knowledge Era" organized by the CGEE in November 2008 in Rio de Janeiro, Conference Proceeings.

Radosevic, S. and A. Reid (2006). "Innovation policy for a knowledgebased economy in Central and Eastern Europe: Driver of growth or new layer of bureaucracy?", in The Knowledge-based Economy in Central and Eastern Europe: Countries and Industries in a Process of Change, eds. K Piech and S Radosevic, pp. 295-311. Basingstoke: Palgrave Macmillan.

Radosevic, Slavo (1998). "The Transformation of National Systems of Innovation in Eastern Europe: Between Restructuring and Erosion" Industrial and Corporate Change, 7(1), 77-108.

Radosevic, Slavo (1999). “Transformation of science and technology systems into systems of innovation in central and eastern Europe: the emerging patterns and determinants" Structural Change and Economic Dynamics, 10(3-4), 277-320.

Radosevic, Slavo (2002). "Introduction: Building the basis for future growth - innovation policy as a solution", Journal of International Relations and Development, 5(4), 352-356.

Radosevic, Slavo (2004). "A Two-Tier or Multi-Tier Europe? Assessing the Innovation Capacities of Central and East European Countries in the Enlarged EU" Journal of Common Market Studies, 42(3), 641-666. Radosevic, Slavo (2006). "The knowledge-based economy in Central and Eastern Europe: An overview of key issues", in The Knowledgebased Economy in Central and Eastern Europe: Countries and Industries in a Process of Change, eds. K Piech and S Radosevic, pp. 3153. Basingstoke: Palgrave Macmillan.

Radosevic, Slavo (2009). "Policies for Promoting Technological Catch Up: Towards a Post-Washington Approach", International Journal of Institutions and Economies, vol. 1, no. 1, 22-51.

Reid, Alastair and Viola Peter (2008). Sectoral Innovation Systems: The Policy Landscape in the EU25, available at www.europe-innova.org.

Rodrik, Dani (2006). 'Goodbye Washington Consensus, Hello Washington Confusion? A Review of the World Bank's Economic Growth in the 1990s: Learning from a Decade of Reform.' Journal of Economic Literature XLIV: 973-987.

Schimmelfennig, F. and U. Sedelmeier (2004). “Governance by conditionality: EU rule transfer to the candidate countries of Central and Eastern Europe", Journal of European Public Policy, 11(4), 669-687.

Tiits, M., R. Kattel, T. Kalvet and D. Tamm (2008). “Catching up, forging ahead or falling behind? Central and Eastern European development in 1990-2005", Innovation. The European Journal of Social Science Research, 21(1), 65-85.

Vargas Alfaro, L. and Segura Bonillla, O., (2003), “Políticas industriales, científicas y tecnológicas en Costa Rica y Centro América", Centro Internacional en Política Económica para el Desarrollo Sostenible 
(CINPE), Universidad nacional, Hereida, Costa Rica.

Wade, R. (1990), Governing the market: economic theory and the role of government in East Asian Industrialization, Princeton University Press

Weissenbacher, Rudy (2007). "Historical Considerations of Uneven Development in East Central Europe", in Becker and Weissenbacher 2007, 35-83.

Williamson, John (2002). "What Washington Means by Policy Reform." Available at http://www.iie.com/publications/papers/paper.cfm? ResearchID $=486$. (Updated version of his 1990 article.)

- (2008). 'Williamson versus the Washington Consensus?' Available at http://www.growthcommissionblog.org/content/williamsonversus-the-washington-consensus

UNIDO (2009). Industrial Development Report 2009. Breaking In and Moving Up: New Industrial Challenges for the Bottom Billion and Middle Income Countries, UNIDO.

World Bank (2006). Economic Growth in the 1990s: Learning from a Decade of Reform. Available at http://www1.worldbank.org/prem/ lessons1990s/

World Bank (2008). Science, Technology, and Innovation. Capacity Building for Sustainable Growth and Poverty Reduction. Available at http:// go.worldbank.org/GEYA2NRGWO

Ylä-Anttila, P. and T. Lemola (2006) "Transformation of Innovation System in a Small Country - the Case of Finland, " in: T. Kalvet and R. Kattel (Eds), Creative Destruction Management: Meeting the Challenges of the Techno-Economic Paradigm Shift, Tallinn: Praxis Center for Policy Studies, 85-99.

Yoguel, G (2003). “La política científica y tecnológica argentina en las últimas décadas: algunas consideraciones desde la perspectiva del desarrollo de procesos de aprendizaje", Trabajo realizado para la CEPAL, Buenos Aires, Argentina.

Young, A. (1994). Gerber products company: Investing in the new Poland. Harvard Business School case study. 


\section{Working Papers in Technology Governance and Economic Dynamics}

The Other Canon Foundation, Norway, and the Technology Governance program at Tallinn University of Technology (TUT), Estonia, have launched a new working papers series, entitled "Working Papers in Technology Governance and Economic Dynamics". In the context denoted by the title series, it will publish original research papers, both practical and theoretical, both narrative and analytical, in the area denoted by such concepts as uneven economic growth, techno-economic paradigms, the history and theory of economic policy, innovation strategies, and the public management of innovation, but also generally in the wider fields of industrial policy, development, technology, institutions, finance, public policy, and economic and financial history and theory.

The idea is to offer a venue for quickly presenting interesting papers scholarly articles, especially as preprints, lectures, essays in a form that may be developed further later on - in a high-quality, nicely formatted version, free of charge: all working papers are downloadable for free from http://hum.ttu.ee/tg as soon as they appear, and you may also order a free subscription by e-mail attachment directly from the same website.

The first nine working papers are already available from the website.

They are

1. Erik S. Reinert, Evolutionary Economics, Classical Development Economics, and the History of Economic Policy: A Plea for Theorizing by Inclusion.

2. Richard R. Nelson, Economic Development from the Perspective of Evolutionary Economic Theory.

3. Erik S. Reinert, Development and Social Goals: Balancing Aid and Development to Prevent 'Welfare Colonialism'.

4. Jan Kregel and Leonardo Burlamaqui, Finance, Competition, Instability, and Development Microfoundations and Financial Scaffolding of the Economy.

5. Erik S. Reinert, European Integration, Innovations and Uneven Economic Growth: Challenges and Problems of EU 2005.

6. Leonardo Burlamaqui, How Should Competition Policies and Intellectual Property Issues Interact in a Globalised World?

A Schumpeterian Perspective

7. Paolo Crestanello and Giuseppe Tattara, Connections and Competences in the Governance of the Value Chain. How Industrial Countries Keep their Competitive Power

8. Sophus A. Reinert, Darwin and the Body Politic: Schäffle, Veblen, and the Shift of Biological Metaphor in Economics 
9. Antonio Serra, Breve Trattato / A Short Treatise (1613) (available only in hardcopy and by request).

10. Joseph L. Love, The Latin American Contribution to CenterPeriphery Perspectives: History and Prospect

11. Ronald Dore, Shareholder capitalism comes to Japan

12. Per Högselius, Learning to Destroy. Case studies of creative destruction management in the new Europe

13. Gabriel Yoguel, Analía Erbes, Verónica Robert, and José Borello, Diffusion and appropriation of knowledge in different organizational structures

14. Erik S. Reinert and Rainer Kattel, European Eastern Enlargement as Europe's Attempted Economic Suicide?

15. Carlota Perez, Great Surges of development and alternative forms of globalization

16. Erik S. Reinert, Iulie Aslaksen, Inger Marie G. Eira, Svein Mathiesen, Hugo Reinert \& Ellen Inga Turi, Adapting to Climate Change in Reindeer Herding: The Nation-State as Problem and Solution

17. Lawrence King, Patrick Hamm, The Governance Grenade: Mass Privatization, State Capacity and Economic Development in Postcommunist and Reforming Communist Societies

18. Reinert, Erik S., Yves Ekoué Amaïzo and Rainer Kattel. The Economics of Failed, Failing and Fragile States: Productive Structure as the Missing Link

19. Carlota Perez, The New Technologies: An Integrated View

20. Carlota Perez, Technological revolutions and techno-economic paradigms

21. Rainer Kattel, Jan A. Kregel, Erik S. Reinert, The Relevance of Ragnar Nurkse and Classical Development Economics

22. Erik S. Reinert, Financial Crises, Persistent Poverty, and the Terrible Simplifiers in Economics: A Turning Point Towards a New "1848 Moment"

23. Rainer Kattel, Erik S. Reinert and Margit Suurna, Industrial Restructuring and Innovation Policy in Central and Eastern Europe since 1990

24. Erkki Karo and Rainer Kattel, The Copying Paradox: Why Converging Policies but Diverging Capacities for Development in Eastern European Innovation Systems?

25. Erik S. Reinert, Emulation versus Comparative Advantage: Competing and Complementary Principles in the History of Economic Policy

26. Erik S. Reinert, Capitalist Dynamics: A Technical Note

27. Martin Doornbos, Failing States or Failing Models?: Accounting for the Incidence of State Collapse 
28. Carlota Perez, The financial crisis and the future of innovation: $A$ view of technical change with the aid of history

29. Rainer Kattel and Annalisa Primi, The periphery paradox in innovation policy: Latin America and Eastern Europe Compared

The working paper series is edited by Rainer Kattel (kattel@staff.ttu.ee), Wolfgang Drechsler (drechsler@staff.ttu.ee), and Erik S. Reinert (reinert@staff.ttu.ee), who all of them will be happy to receive submissions, suggestions or referrals. 